\title{
Early and late Outcome, Mortality and major Morbidity after Lung Cancer Surgery for Primary Carcinoma.
}

\author{
F. Gradica ${ }^{1 *}$, L. Lisha ${ }^{1}$, Dh. Argjiri ${ }^{1}$, A. Cani ${ }^{1}$, F. Kokici ${ }^{1}$, F. S. Gradica ${ }^{2}$, V. Rexha ${ }^{2}$, D. Lala ${ }^{2}$, \\ D. Xhemalaj ${ }^{1}$, Y. Vata ${ }^{1}$, L. Shpataraku ${ }^{1}$, A.Vyshka ${ }^{1}$
}

Received: 02 March 2018; Accepted: 30 June 2018; Published online: 20 July 2018. DOI; $\underline{\text { https://doi.org/10.32391/ajtes.v2i2.12 }}$

\section{Abstract}

Background: Radical surgical resection of lung cancer with or without adjuvant treatment is still a prerequisite for cure. Advances in operative and postoperative care led to a decline in complications and mortality rates during the last decades. In spite of different additional modes of treatment, survival is still poor.

The aim of study: To examine the operative mortality and morbidity after lung cancer surgery and to identify factors associated with an adverse outcome.

Material and methods: The study comprised 968 consecutive patients referred to University Hospital of Lung Disease, "Shefqet Ndroqi" Tirana, Albania, for lung carcinoma, during a 13-years period (January 2004-December 2017). All patients underwent routine laboratory examinations spirometry and preoperative CT- scan of the thorax and upper abdomen. PET-CT, EBUS-EUS, Mediastinotomy or Mediastinoscopy wasn't performed as routine.

Results: Of 968 patients, 690 (70.5\%) were male and 278 (28.7\%) female. Mean age 65.5 \pm 9.4 years (range 15 87 years). Lobectomy was the most used surgical modality in 566 (58.5\%) patients, meanwhile pneumonectomy was performed in 112 (11.6\%) of patients. Minor complications during surgery occurred in $45(11.7 \%)$ of patients. Continuous air leakage was the most complication after surgery in $25.3 \%$, followed by lung atelectasis in $21.3 \%$ and cardiovascular complications in $17 \%$.

Conclusion: our results show low mortality and morbidity after lung cancer surgery. However, patients with reduced lung capacity, older age and those undergoing pneumonectomy should be treated with great care. Key words: Outcome, complications, lung cancer, thoracic surgery.

*Corresponding author: Fadil Gradica $\equiv \lambda$ Email:fadil_gradica68@hotmail.com

${ }^{1}$ University Hospital, "Shefqet Ndroqi" Tirana, Albania

2Public pharmacy and odontology Service Tirana 


\section{Introduction}

Lung cancer (Figures 1-5) is the most common form and cause of cancer death world-wide. Radical surgical resection, with or without adjuvant treatment, is still a prerequisite for cure. In European countries the proportion of patients who undergo surgery for this disease varies between 10 and $20 \%$. Advances in operative and postoperative care have led to a decline in complications and mortality rates during the last two decades (1). In spite of different additional modes of treatment, survival is still poor. To be able to improve the quality of operative procedures it is important: to identify patients running the highest risk, optimizing the patient's condition, medication and respiratory status before surgery, to have knowledge of peri and postoperative mortality and morbidity, and also of risk factors prior to surgery.

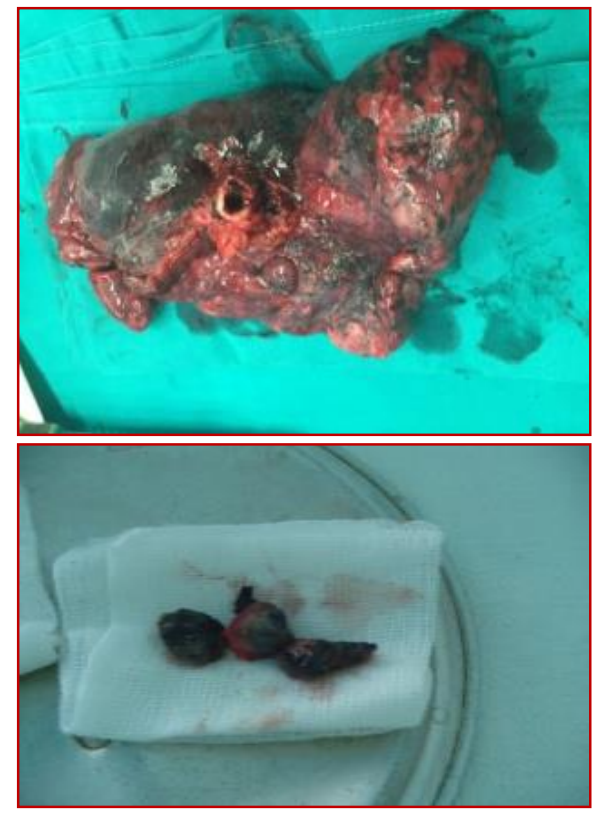

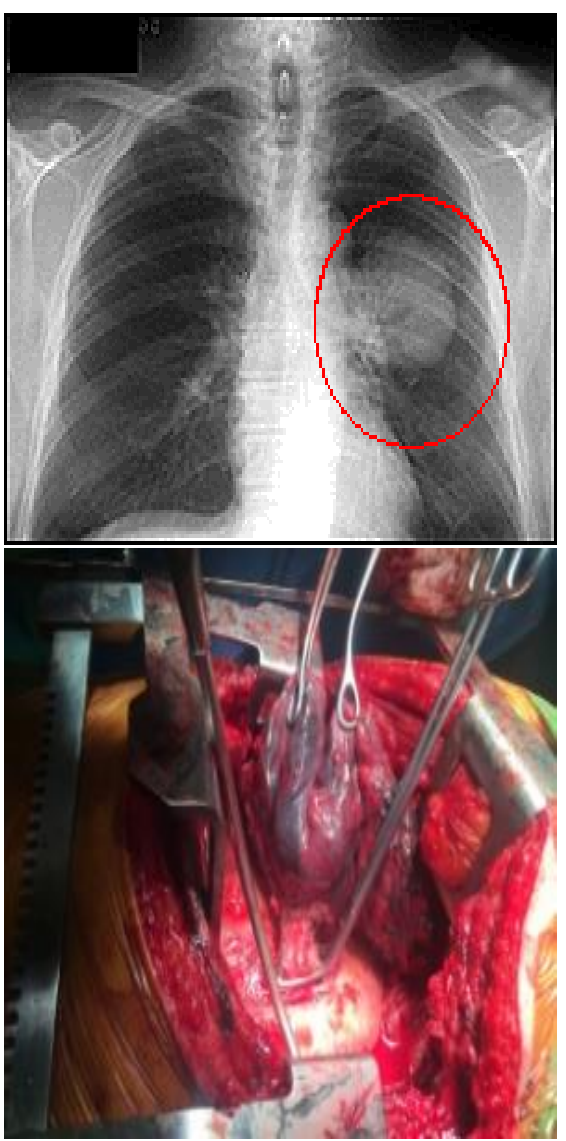

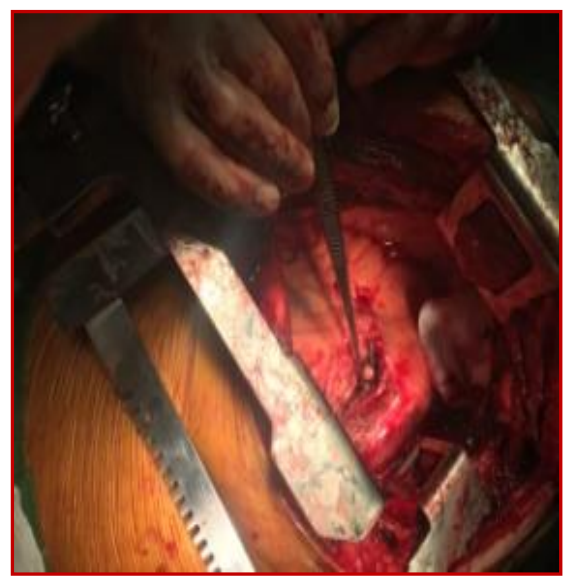

Figures 1-5: 1-X-ray view; 2,3-Operative view; 4,5-Macroscopic specimens

\section{Results}

Of 968 patients, 690 (70.5\%) were male and 278 (28.7\%) female. Mean age 65.5 \pm 9.4 years (range 15 
- 87 years), of them 271 (27.9\%) patients were over

70 years. No differences is seen in death between

gender (female vs. male $3.6 \%$ vs. $3.9 \%$ respectively;

$\mathrm{p}=0.476)$.

\begin{tabular}{|c|c|c|c|c|c|}
\hline $\begin{array}{l}\text { Demographic } \\
\text { characteristic }\end{array}$ & Patients & Death within & 30 days & $\begin{array}{l}\text { Major } \\
\text { complication }\end{array}$ & \\
\hline & N (\%) & N (\%) & $P$-value & N (\%) & P-value \\
\hline $\begin{array}{r}\text { Age } \\
<70 \text { years } \\
\geq 70 \text { years }\end{array}$ & $\begin{array}{l}697(72.1) \\
271(27.9)\end{array}$ & $\begin{array}{l}18(2.6) \\
19(7.0)\end{array}$ & 0.039 & $\begin{array}{l}23(3.3) \\
25 \underline{(9.2)} *\end{array}$ & 0.0024 \\
\hline $\begin{array}{r}\text { Gender } \\
\text { Female } \\
\text { Male }\end{array}$ & $\begin{array}{l}278(28.7) \\
690(70.5)\end{array}$ & $\begin{array}{l}10 \\
(3.6) \\
27(3.9)\end{array}$ & 0.476 & $\begin{array}{l}20(7.1) \\
28(4,0)\end{array}$ & 0.984 \\
\hline $\begin{array}{r}\text { Co morbidity } \\
\text { Yes } \\
\text { No }\end{array}$ & $\begin{array}{l}257(26.6) \\
711(73.4)\end{array}$ & $\begin{array}{l}17(6.8) \\
20(2.8)\end{array}$ & 0.064 & $\frac{29(\underline{11.2)}}{9(1.24)} *$ & 0.0001 \\
\hline Total cases & $\begin{array}{l}968 \\
(100)\end{array}$ & $37(3.8)$ & & $48(7.2)$ & \\
\hline
\end{tabular}

Table 1: Patient characteristics in relation to death within first 30 days of surgery and major complications

According to histopathology most of patients result squamous cell carcinoma (56\%), followed by adenocarinoma (36\%) and the rest other types. Significant difference in mortality within 30 days is seen between adenocarcima, squamous cell carcinoma and other type of cancer $((2,7 \%, 3.8 \%$ vs. $12.6 \%$ respectively; $p<0.01)$. In spite major complications were in other group of cancer no significant differences is seen between groups. Over $2 / 3$ of patients $78 \%$ were current smokers and only $22 \%$ never smokers. No differences are seen in term of death or major complications among the groups ( $2.6 \%$ vs. $2.0 \%$ and $6.4 \%$ vs. $9.4 \%$ respectively). Lung function is the parameter of particular importance as a prognostic factor in evaluation of patients after surgery. A significant difference in patients is seen with FEV $1<70 \%$ compared with them with FEV1> 70\% in term of mortality and major complications $(10.7 \%$ vs. $2.3 \%$ and $23,8 \%$ vs. $2.6 \%$ respectively. 


\section{Patients Mortality ( $\quad$ 30-days) Major complications}

\begin{tabular}{|c|c|c|c|c|c|c|}
\hline \multirow{2}{*}{ Histopathological typ } & \multicolumn{2}{|c|}{$(\mathrm{Nr} . \%)$} & \multicolumn{2}{|c|}{$(N r . \%)$} & \multicolumn{2}{|c|}{ (Nr. \% } \\
\hline & & & & & & \\
\hline Adenocarcinoma & 348 & 36 & 9 & 2.7 & 26 & 7.6 \\
\hline Squamous cell ca. & 542 & 56 & 21 & 3.8 & 35 & 6.4 \\
\hline Other types & 78 & 8 & 9 & $12.0^{*}$ & 9 & 12.0 \\
\hline
\end{tabular}

\section{Smoking habits}

Smoker

Never smoked

Lung function (FEV1, \%)

FEVI $>70 \%$

FEVI $<70 \%$

$756 \quad 78$

$212 \quad 22$

$\begin{array}{ll}765 & 79 \\ 203 & 21\end{array}$

20

4

2.6

17

22

$\begin{array}{cc}48 & 6.4 \\ 20 & 9.4\end{array}$

$20 \quad 2.6$

$10.7 * *$

Table 2: Mortality and major complications, tumor and patient characteristic, (nr. \%); *statistically significant

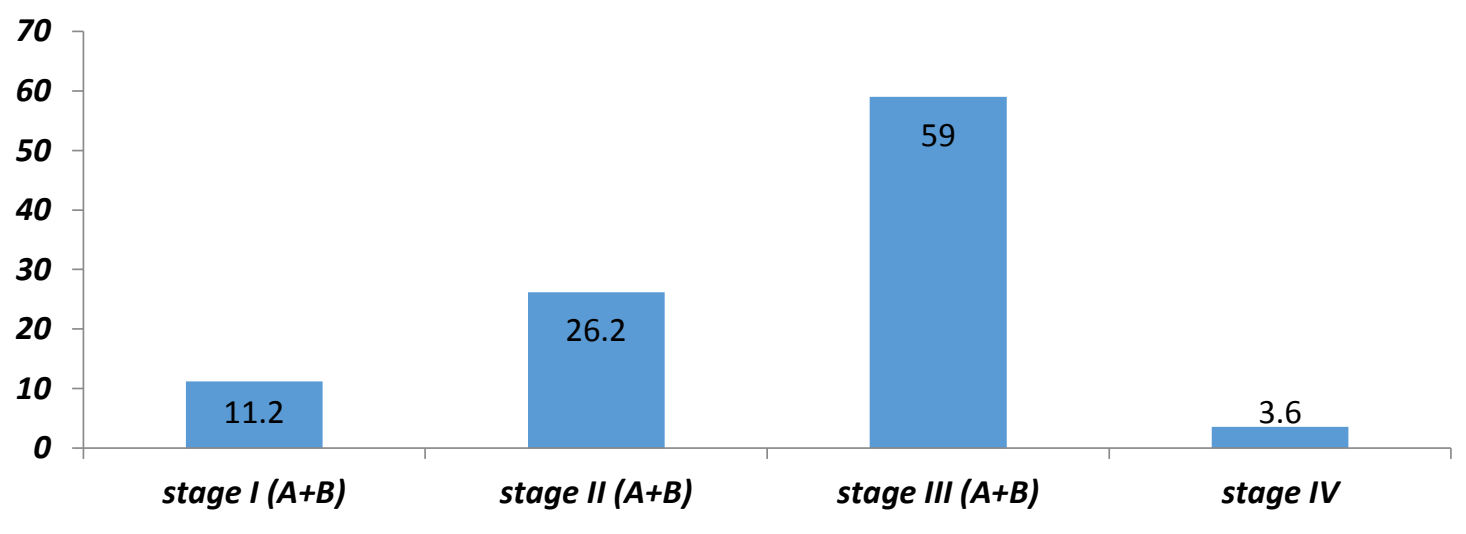

Table 3: Stage of diseases and surgery modality.

It is noted that the largest number of patients belonging to stage III + IV (63\%) of cases, compared to $37 \%$ in stages I + II. Single lobectomy (58\%) predominate significantly versus other types of surgery.

Lobectomy was the most used surgical modality in 566 (58.5\%) patients, meanwhile pneumonectomy was performed in $112(11.6 \%)$ of patients. Minor complications during surgery occurred in 45 (11.7\%) of patients. 
Continuous air leakage was the most complication Mortality Major complications

Surgery approach Patients within (Nr, \%)

30-days,

$(N, \%)$

\begin{tabular}{r|llllll} 
Pneumonectomy & 112 & 13.4 & 15 & 13.4 & 30 & 26.7 \\
Right & 42 & 4.4 & 11 & 26.1 & 20 & 39.2 \\
Left & 70 & 7.2 & 4 & 5.7 & 10 & 14.3 \\
Lobectomy & 566 & 58.5 & 7 & 1.2 & 16 & 2.8 \\
Bilobectomy & 126 & 13 & 7 & 6 & 8 & 8 \\
$\begin{array}{r}\text { Explorative } \\
\text { thoracotomy }\end{array}$ & 51 & 5.3 & 5 & 9.8 & 5 & 9 \\
$\begin{array}{r}\text { Wedge, } \\
\text { Segmentectomy }\end{array}$ & 107 & 11 & 3 & 3 & 3 & 3 \\
Total & 968 & $100 \%$ & 37 & 3.8 & 62 & 6.4
\end{tabular}

Table 4: Patient characteristics according surgery modalit

The 30 days mortality rate was 3.8\% (37) patients, $1.2 \%$ after single lobectomy and $13.4 \%$ after after surgery in $25.3 \%$, followed by lung atelectasis pneumonectomy.

in $21.3 \%$ and cardiovascular complications in $17 \%$.

Of the life-threatening complications respiratory failure was the most events in $20.0 \%$ of patients,

followed by Broncho-pleural fistula in $18.7 \%$ and pulmonary edema in $15 \%$ of patients.

\begin{tabular}{|c|c|c|c|c|c|}
\hline Minor complications & Nr. & $\%$ & $\begin{array}{c}\text { Major } \\
\text { Complications }\end{array}$ & Nr. & $\%$ \\
\hline $\begin{array}{l}\text { Supra-ventricular } \\
\text { arrhythmias }\end{array}$ & 13 & 17.3 & Respiratory failure & 10 & 20.8 \\
\hline $\begin{array}{l}\text { Continuous } \\
\text { Air leakage }\end{array}$ & 19 & 25.3 & $\begin{array}{l}\text { Broncho-pleural } \\
\text { fistulas }\end{array}$ & 9 & 18.75 \\
\hline $\begin{array}{l}\text { Lung } \\
\text { Atelectasis }\end{array}$ & 16 & 21.3 & Pulmonary edema & 7 & 14.6 \\
\hline Obstructive symptoms & 11 & 14.6 & Cardiac failure & 6 & 12.5 \\
\hline $\begin{array}{l}\text { Paresis of recurrent } \\
\text { Nerve }\end{array}$ & 1 & 1.3 & Tumor embolism & 5 & 10.4 \\
\hline $\begin{array}{l}\text { Insufficient wound } \\
\text { healing }\end{array}$ & 4 & 5.3 & Myocardial infarction & 3 & 6.25 \\
\hline
\end{tabular}




\begin{tabular}{l|cclcc} 
Diaphragmatic paresis & 6 & 8.0 & Chilothorax & 3 & 6.25 \\
$\begin{array}{l}\text { Mediastinal } \\
\text { Shift displacement }\end{array}$ & 5 & 6.6 & Postoperative bleeding & 4 & 8.3 \\
& & & Cerebral infarction & 1 & 2.0 \\
Total & 75 & $7.7 \%$ & Total & 48 & $4.9 \%$
\end{tabular}

Table 5: Minor and Major Complications within first 30 days after surgery, (7.7\% vs.4.9\%)

\section{Discussion}

Bronchial cancer today represents a health problem all over the world and one third of them meet at the age of 70 (1-3). In our study there have been $70.5 \%$ male and $28.7 \%$ female. This is closely related to the smoking habit which is widespread in males. The number of tobacco users affected by pulmonary cancer in our country in a study conducted at our hospital by Vakeflliu. $Y$ and al. results up to $86.6 \%$ of cases. We found differences is seen in death between gender (female vs. male $3.6 \%$ vs. $3.9 \%$ respectively; $p=0.476$ ).

In this study, the age of the intervening pulmonary carcinoma varies from 15 to 87 years. Of 968 cases in total 271 patients were over 70- years old. Mortality and major complications result with significant differences comparing to those under 70 years old ( $p=0.03$ and 0.0024 respectively). Nevertheless, old age alone does not appear to be a definite contraindication to surgery

There are surgical experiences in patients over 70 years, which indicate that this therapeutic strategy can be performed with good results (11-13). Shirakuza et al. (11), in a series of 33 patients older than 80 years, operated for pulmonary tumor, conclude that, in an elderly subject, not age, but the spread of the disease and the cardio-pulmonary reserve should guide the choice of intervention. Also significant differences are seen according to patients with co morbidity. Furthermore, previous studies have indicated that concomitant diseases such as ischemic heart disease, diabetes mellitus or chronic obstructive lung disease represent significant risk factors for an adverse outcome. The histological examination of the material in this study shows the significant predominance of the squamous cell carcinoma and adenocarcinoma versus other types. However, based on the sex of the patients, predominance of adenocarcinoma is observed in females, due to the increase in the number of smokers.

Surgical treatment of pulmonary cancer is the method chosen for stage I and II. Procedures that save pulmonary parenchyma offer lower mortality and morbidity than pneumonectomy and instability when complete resection has taken place. (12) Lung function is the parameter of particular importance as a prognostic factor in evaluation of patients after surgery. In this study a significant difference in patients is seen with $\mathrm{FEV} 1<70 \%$ compared with them with FEV1 $>70 \%$ in term of mortality and major complications ( $10.7 \%$ vs. $2.3 \%$ and $23,8 \%$ vs. $2.6 \%$ respectively.

According to the extent of pulmonary resection, the largest number of cases is treated with lobectomy (58\%) followed by bilobectomy and pneumonectomy (13\%) and segmentectomy (11\%), less is performed explorative thoracotomy [ $p$ $<0.001$.

As expected, the mortality was higher following pneumonectomy (13.4\%) than other type of surgery.

The major complications most often related to a postoperative death were respiratory failure (20.0\%) followed by Broncho-pleural fistula in 
$18.7 \%$ and pulmonary edema in $15 \%$ of patients. These data are in accordance with other reports. In several studies risk factors for major complications after lung resections have been identified, namely: age, male sex, smoking and concomitant disease. As confirmed in the present study, a low respiratory capacity, assessed as FEV1\% and pneumonsctomy, appears to be the most important predictor of a high risk of complications after lung resections.

Our results confirm that low mortality $3.8 \%$ and an acceptable level of major morbidity $6.4 \%$ can be achieved after surgical resections for lung cancer, especially after single lobectomies (1.2\%).

\section{Conclusion}

Our results show low mortality and morbidity after lung cancer surgery. However, patients with reduced lung capacity and those undergoing pneumonectomy should be treated with great care, as they run a considerable risk of major complications or death during the first 30 days postoperatively. Older age (>70 yrs), does not appear to be a contraindication to lung cancer surgery, but patients in this group should undergo careful preoperative evaluation. Pneumonectomy sinister et systemic mediastinal lyphonodulectomy ca bronchopulmonare hilare sinister, post neoadjubvant chemiotherapy.

\section{References}

1-Pastorino U, Yang XN, Massimo F, et al. Long-term survival after salvage surgery for invasive thymoma with intracardiac extension. Tumori 2008; 94: 7726. 2-Solaini L, Prusciano F, Bagioni P, et al. Long-term results of video-assisted thoracic surgery lobectomy for stage I non-small cell lung cancer: a single- centre study of 104 cases. Interact Cardiovasc Thorac Surg 2004; 3: 57-62.

3-Imperatori A, Mariscalo G, Riganti G, et al. Atrial fibrillation after pulmonary lobectomy for lung cancer affects long-term survival in a prospective single-center study. J Cardiothorac Surg 2012; 7: 4. 4-Daly BD, Fernando HC, Ketchedjian A, et al. Pneumonectomy after high-dose radiation and concurrent chemotherapy for nonsmall cell lung cancer. Ann Thorac Surg 2006; 82: 227-31. 5-Inoue $M$, Okumura $M$, Minami $M$, et al. Cardiopulmonary co-morbidity: a critical negative prognostic predictor for pulmonary resection following preoperative chemotherapy and / or radiation therapy in lung cancer patients. Gen Thorac Cardiovasc Surg 2007; 55: 315-21 6-Lally BE, Detterbeck FC, Geiger AM, et al. The risk of death from heart disease in patients with nonsmall cell lung cancer who receive postoperative radiotherapy: analysis of the Surveillance, Epidemiology, and End Results database. Cancer 2007; 110: 911-7.

7-Saha SP, Kalathiya RJ, Davenport DL, et al. Survival after pneumonectomy for stage III non-small cell lung cancer. Oman Med J 2014; 29: 24-7. Von Knorring J, Lepantalo $\mathrm{M}$, Lindgren L, et al. Cardiac arrhythmias and myocardial ischemia after thoracotomy for lung cancer. Ann ThoracSurg 1992; 53: 642-7.

8-Toker, A., Dilege, S., Ziyade, S. et al, Causes of death within 1 year of resection for lung cancer (Early mortality after resection). Eur J Cardiothorac Surg. 2004; 25: 515-519.

9- Thomas P, Sielezneff I, Ragni J, et al. Is lung cancer resection justified in patients aged over 70 years? Eur J Cardiothorac Surg 1993; 7: 246-50; discussion 250-1.

10- Ploeg AJ, Kappetein AP, van Tongeren RB, et al. Factors associated with perioperative 
complications and long-term results after pulmonary resection for primary carcinoma of the ;lung. Eur J Cardiothorac Surg 2003; 23: 26-9. 11- Hollings DD, Higgins RSD, Faber Penfield L, et al. Age is a strong risk factor for atrial fibrillation after pulmonary lobectomy. Am J Surg 2010; 199: 558-61.

12- Kalathiya RJ, Saha SP. Pneumonectomy for nonsmall cell lung cancer:outcomes analysis.

South Med J 2012; 105: 350-4.
13- Piehler JM, Trastek VF, Pairolero PC, et al. Concomitant cardiac and pulmonary operations. J Thorac Cardiovasc Surg 1985; 90: 662-7. 14- Canver CC, Bhayana JN, Lajos TZ, et al. Pulmonary resection combined with cardiac operations. Ann Thorac Surg 1990; 50: 796-9. 15-Adant JP, Defraigne JO, Limet R. Combined one stage cardiac and pulmonary surgery by median sternotomy. Acta Chir Belg 1990; 90: 97-202. 